\title{
HUBUNGAN ANTARA KADAR IMMUNOGLOBULIN E SERUM DENGAN LAMANYA PASIEN MENDERITA ONIKOMIKOSIS
}

\author{
Meidina K. Wardani, Eva Hariani, Cut Mirshella Amanda \\ Departemen Ilmu Kesehatan Kulit dan Kelamin \\ FK Universitas Sumatera Utara/RSUP H Adam Malik, Medan
}

\begin{abstract}
ABSTRAK
Imunologi dari onikomikosis masih belum sepenuhnya dipahami. Pemahaman respons imun terhadap penyakit onikomikosis mungkin dapat membuka wawasan baru terhadap patogenesis dan terapi. Berdasarkan beberapa laporan kasus dan penelitian sebelumnya dijumpai kadar immunoglobulin E (IgE) serum yang lebih tinggi pada pasien asma, rinitis, atau urtikaria yang menderita onikomikosis. Penelitian ini dilakukan untuk menilai hubungan antara kadar IgE serum dengan lamanya menderita onikomikosis pada populasi umum.

Penelitian ini merupakan studi analitik dengan pendekatan potong lintang (cross sectional) yang melibatkan 20 pasien onikomikosis. Setelah diagnosis onikomikosis ditegakkan, pada setiap sampel dicatat lama sakit dan kemudian dilakukan pemeriksaan kadar IgE serum. Penelitian dilakukan di RSUP H. Adam Malik Medan pada bulan Juli 2016.

Tidak dijumpai hubungan antara kadar IgE serum pasien onikomikosis dengan lama sakit (nilai $p=0,959)$. Nilai rata-rata lamanya pasien menderita onikomikosis adalah 64,80 (simpang baku 10,12) bulan Kadar minimum imunoglobulin E serum 9,17 IU/mL dan kadar maksimumnya 8,388,20 IU/mL, serta nilai rata-rata 1,337,73 (simpang baku 472,55) IU/mL.

Hasil penelitian ini menunjukkan tidak terdapat hubungan yang bermakna antara kadar immunoglobulin E serum pasien dengan lamanya menderita onikomikosis. Dari beberapa penelitian di Indonesia sebelumnya mengenai hubungan antara kadar imunoglobulin E serum dengan onikomikosis belum menunjukkan hasil yang konsisten.
\end{abstract}

Kata kunci: Onikomikosis, immunoglobulin E, lama sakit

\section{CORRELATION BETWEEN SERUM IMMUNOGLOBULIN E LEVEL WITH DURATION OF ONYCHOMYCOSIS}

Korespondensi:

Jl. Bunga Lau No. 17 Medan

Telp. 061-836014

Email: Meidinawardani01@gmail.com

\begin{abstract}
Immunology of onychomycosis is poorly understood. The understanding of immune responsses to the disease may provide new insights on its pathogenesis and for therapy. Based on several case reports and recent studies have found that serum immunoglobulin $E$ (IgE) levels were higher in patients with asthma, rhinitis, or urticaria with onychomycosis. This study was conducted to assess the correlation between serum levels of IgE with duration of having onychomycosis in general population.

This descriptive analytical cross sectional study involving 20 patients onychomycosis. Diagnosis of onychomycosis confirm by patient history, clinical finding, and $\mathrm{KOH}$ examination. Duration of patients having onychomycosis was recorded for each sample and then their serum IgE level was examined. This study was held at H. Adam Malik General Hospital, Medan during July 2016.

There was no correlation between serum IgE levels with duration of patients having onychomycosis with $p$ value $=0.959$. The mean of duration $64.80 \pm 10.12$ months. Serum IgE minimum level 9.17 IU/mL and maximum level 8.388,20 IU/mL (mean $=1.337 .73 \pm 472.55 \mathrm{IU} / \mathrm{mL})$.

In Indonesia there is still limited research regarding the correlation between serum immunoglobulin $E$ with onychomycosis. Some previous studies correlating serum levels of immunoglobulin E with chronic yeast infections had not shown consistent results. Results of this study showed there was no significant correlation between serum immunoglobulin E levels with duration of patients having onychomycosis.
\end{abstract}

Keyword: Onychomycosis, immunoglobulin E, duration of having Onychomycosis 


\section{PENDAHULUAN}

Onikomikosis adalah istilah umum untuk infeksi pada kuku yang disebabkan oleh jamur dermatofita, jamur nondermatofita, maupun yeast. Pada kebanyakan kasus, onikomikosis disebabkan oleh dermatofita yaitu Trichophyton rubrum dan Trichophyton interdigitale sebagai penyebab pada lebih dari $90 \%$ kasus. ${ }^{1,2}$ Mekanisme pertahanan tubuh yang utama terhadap jamur adalah melalui pertahanan tubuh non-spesifik. Dalam hal ini termasuk sawar mekanis dan kimia pada kulit dan membran mukosa, bakteri sebagai flora normal. Peranan komplemen dan antibodi spesifik sebagai pertahanan tubuh terhadap infeksi jamur telah lama diteliti, namun sampai saat ini hubungannya secara pasti masih belum diketahui. Sementara beberapa antibodi spesifik kerap ditemukan pada serum pasien yang terinfeksi jamur.,

Trichophyton dapat memicu alergi karena ikatan antibodi IgE dan Trichophyton dengan monosensitisasi sehingga alergi terhadap Trichophyton ini hanya dapat dilihat dari pemeriksaan spesifik yaitu Radioallergosorbent testing (RAST). Sedangkan terkadang pemeriksaan skin pritch test dapat menunjukkan hasil negatif terhadap jamur. Hal ini terbukti pada suatu penelitian didapatkan peningkatan antibodi IgE sebanyak 31\% dan 16,5\% sensitif terhadap Trichophyton. Terdapat juga penelitian yang menemukan ekstrak Trichophyton pada hiper reaktivitas bronkus. ${ }^{6}$

Di Indonesia hingga saat ini masih sangat terbatas penelitian yang menghubungkan kadar imunoglobulin E serum dengan onikonikosis. Peneliti belum pernah mendapatkan data mengenai hubungan antara kadar imunoglobulin E serum dengan lamanya menderita onikomikosis. Oleh karena itu peneliti memandang perlu dilakukan penelitian untuk menilai hubungan antara kadar immunoglobulin E serum dengan lamanya menderita onikomikosis.

\section{METODE}

Penelitian ini merupakan studi analitik dengan pendekatan potong lintang (cross sectional) dilaksanakan mulai dalam bulan Juli 2016 sampai jumlah sampel terpenuhi. Penelitian ini dilaksanakan di SMF Ilmu Kesehatan Kulit dan Kelamin Divisi Mikologi RSUP H. Adam Malik Medan dan pengambilan sampel darah untuk pemeriksaan imunoglobulin E dilakukan di laboratorium klinik Pramita Medan.

Kriteria inklusi adalah 1) pasien yang didiagnosis secara klinis dan pemeriksaan $\mathrm{KOH} 20 \%$ sebagai pasien onikomikosis; 2) usia antara 20-70 tahun; 3) bersedia ikut serta dalam penelitian dan menandatangani informed consent. Kriteria eksklusi adalah 1) hamil dan menyusui; 2) konsumsi kortikosteroid/imunosupresan selama lebih kurang 2 minggu terakhir; 3) pasien dengan dermatitis yang luas, penyakit keganasan, penyakit autoimun, psoriasis kuku, liken planus, atau kelainan kuku yang lain. Sampel penelitian diambil secara consecutive sampling.

Sebanyak $3 \mathrm{ml}$ sampel darah vena subjek penelitian dimasukkan ke dalam tabung sentrifugasi. Selanjutnya darah disentrifugasi selama \pm 5 menit untuk mendapatkan serum. Pengukuran kadar immunoglobulin E serum dengan metode Enzyme Linked Fluorescent Assay (ELFA) dengan reagen biomerieux dari PT. Enseval. Kemudian subjek penelitian dianamnesis mengenai lama penyakit atau timbulnya onikomikosis, yaitu sejak pasien mengeluhkan adanya kelainan kuku. Uji korelasi Spearman digunakan untuk menilai hubungan kadar IgE dengan lamanya menderita onikomikosis. Kemaknaan statistik apabila nilai $p<0,05$.

Penelitian ini sudah memperoleh ethical clearance dari Komite Etik Penelitian Bidang Kesehatan Fakultas Kedokteran Universitas Sumatera Utara.

\section{HASIL}

Hubungan antara kadar IgE serum pasien onikomikosis dengan durasi onikomikosis dapat dilihat pada tabel 1 .

Tabel 1. Korelasi antara kadar IgE serum dengan lama menderita onikomikosis

\begin{tabular}{lcccc}
\hline \multicolumn{1}{c}{ Variabel } & Rerata & $\mathrm{r}^{*}$ & $P$ & Signifikansi \\
\hline Kadar IgE & $1.337,73 \pm 472,55$ & $-0,012$ & 0,959 & Tidak signifikan \\
$\begin{array}{l}\text { Durasi } \\
\text { onikomikosis }\end{array}$ & $64,80 \pm 10,12$ & $-0,012$ & 0,959 & Tidak signifikan \\
\hline & *Spearman correlation coefficient & & & \\
\end{tabular}

Pada tabel 1 dapat dilihat bahwa nilai rata-rata imunoglobulin E serum dari 20 pasien wanita onikomikosis pada penelitian ini adalah $1.337,73 \pm 472,55 \mathrm{IU} / \mathrm{mL}$ dengan kadar minimum imunoglobulin E serum 9,17 IU/mL dan kadar maksimumnya 8.388,20 IU/mL. Berdasarkan hasil uji analisis statistik dengan uji Spearman dapat dilihat bahwa tidak terdapat hubungan yang bermakna antara kadar imunoglobulin E serum pasien onikomikosis dengan lamanya menderita onikomikosis (nilai $\mathrm{p}=0,959$ ).

\section{PEMBAHASAN}

Imunoglobulin atau antibodi adalah sekelompok glikoprotein yang terdapat dalam serum atau cairan tubuh pada hampir semua mamalia. Imunoglobulin termasuk dalam famili glikoprotein yang mempunyai struktur dasar sama, terdiri atas $82-96 \%$ polipeptida dan $4-18 \%$ karbohidrat, komponen polipeptida membawa sifat biologik molekul antibodi tersebut. Immunoglobulin $\mathrm{E}$ (IgE) juga disebut reaginic antibody, yang merupakan faktor penting dalam reaksi alergi dan sebagai pelindung terhadap infeksi parasit. Bagian dari IgE, yaitu Fc, akan berikatan dengan reseptor yang berafinitas tinggi yaitu sel 
mast. Saat kontak dengan antigen, IgE memicu degranulasi sel, menghasilkan pelepasan zat aktif farmakologi yang memperantarai reaksi hipersensitivitas. ${ }^{3}$

Hubungan antara fungsi biologi enzim jamur terhadap alergenisitas dan patogenesis penyakit masih belum diketahui pasti. Alergen adalah protein dengan berat molekul rendah atau glikoprotein yang dapat menginduksi antibodi IgE pada manusia., ${ }^{4,}$ Gupta dkk. mendapatkan total IgE yang lebih tinggi pada onikomikosis daripada kontrol. Hal ini sesuai dengan penelitian sebelumnya yang menyatakan bahwa IgE total meningkat pada dermatofita kronik. Kenaikan total IgE, walaupun tidak spesifik, dapat menjadi penanda probabilitas sensitisasi jamur awal. ${ }^{6}$

Pada tahun 1949 pertama kali muncul laporan mengenai peningkatan insidensi riwayat alergi pada pasien dengan infeksi jamur kronik. Pada tahun 2000, Escalante dkk. meneliti insidensi infeksi jamur pada subjek atopik dan nonatopik dengan hasil yang menunjukan tidak ada hubungan antara status atopik dengan infeksi dermatofita walaupun tetap dijumpai peningkatan prevalensi hasil positif uji kulit terhadap Trichophyton. Pada tahun 1980, Jones memperkenalkan istilah "atopic-chronic dermatophytosis syndrome" yaitu kondisi terdapat hubungan antara rinitis alergi atau asma dengan infeksi tinea kronik disertai peningkatan kadar total IgE dan kadar IgE yang spesifik. ${ }^{7}$

Infeksi kronis dermatofita mengakibatkan perubahan polarisasi $\mathrm{T}$ sel efektor yang mengakibatkan perubahan keseimbangan Th1 dan Th2. Sel Th1 dan Th17 bertanggung jawab sebagai proteksi imunitas terhadap jamur. Sementara respons Th2 berhubungan dengan menghilangkan efek tersebut. Berdasarkan beberapa laporan kasus, infeksi jamur kronik berhubungan dengan hipersensitivitas tipe I atau immediate hypersensitivity (IH). Hal ini menimbulkan dasar pertimbangan bahwa disregulasi sistem imun berpengaruh pada perkembangan penyakit tertentu sehingga timbul dugaan bahwa peningkatan insidensi onikomikosis yang terjadi pada usia lanjut merupakan akibat perubahan respons imun. Selain itu juga terdapat laporan mengenai hubungan dermatitis atopik dengan dematofitosis kronik yang menimbulkan dugaan bahwa respons Th2 mempengaruhi infeksi persisten.,

Hubungan antara atopik dengan dermatofitosis kronik ini sesuai dengan peningkatan kadar IgE pada serum pasien dengan dermatofitosis kronik. Namun ternyata dijumpai hasil kadar IgE yang normal pada penelitian lain dengan subjek yang mengalami Athlete's foot. ${ }^{7}$

Penelitian oleh Escalante dkk. menemukan bahwa kadar IgE total pada pasien bukan atopik dengan dan tanpa mikosis adalah sebanding, ${ }^{7}$ namun hingga saat ini masih sangat terbatas penelitian yang menghubungkan kadar IgE serum dengan onikomikosis. Dan peneliti belum pernah mendapatkan data mengenai hubungan antara kadar IgE serum dengan lamanya menderita onikomikosis.

\section{SIMPULAN}

Hasil penelitian ini tidak menunjukkan hubungan yang bermakna antara kadar IgE serum pasien onikomikosis dengan lamanya menderita onikomikosis.

\section{DAFTAR PUSTAKA}

1. Schieke SM, Garg A. Superficial fungal infection. Dalam: Goldsmith LA, Katz SI, Gilchrist BA, Paller AS, Leffel DJ, Wolff $\mathrm{K}$, penyunting. Fitzpatrick's Dermatology in General Medicine. Edisi ke-8. New York: McGraw Hill Companies; 2012.h. 2292-6.

2. Seebacher C, Brasch J, Cornely DAO, Effendy I, Hanselmayer GG, Haake N dkk. Onychomycosis. J Compilation Blackwell Pub. Mycoses 2007; 50:321-27.

3. Bos JD. Skin immune system (SIS). Dalam: Bos JD, penyunting. Skin immune system, cutaneous immunology and clinical immunodermatology. Edisi ke-3.Florida: CRC Press LLC, 2005.h.3-11.

4. Leibovici V. Imbalance of immune responsses in patients with chronic and widespread fungal skin infection. Clin Exper Dermatol. 1995; 20: 390-394.

5. Bayston $\mathrm{K}$, Tang $\mathrm{C}$, Cohen J. Immunology of fungal infection. Dalam: Sissons JGP, Borysiewicz LK, Cohen J, penyunting. Immunology of infection. Kluwer Academic Publishers; 1994.h.49-85.

6. Gupta C, Das S, Ramachandran VG, Saha R, Bhattacharya SN, Dar SA, Atri D. Possible role of trichophytin antigen in inducing impaired immunological clearance of fungus in onychomycosis. Mycophatol. 2016;181:247-51.

7. Escalante MT, Borges MA, Hullet AC, Blagio ED, Avelego LG. Trichophyton specific IgE in patients with dermatophytosis is not associated with aeroallergen sensitivity. J Allergy Clin Immunol. 2000;105(3):547-50. 